\title{
BRAND MANAGEMENT - THEORY AND PRACTICE IN THE FOOTBALL ACADEMIES IN BULGARIA
}

\author{
Nina Atanasova, Emil Atanasov \\ National Sports Academy "Vassil Levski”, Sofia, Bulgaria
}

\begin{abstract}
Football attracts the attention of a number of researchers who study the management of football clubs and academies in different countries. The focus is on the managerial philosophy, goal setting, organization of the sports training process and others. An important element in the business management of football clubs is the use of marketing techniques - active communication, targeted pro-

motional activities, the choice of communication constants to impose corporate identity and reputation.

The purpose of this research was to examine the experience and operational capabilities of some football academies in Bulgaria in creating a corporate identity and establishing a football brand. The research tasks were related to: researching literary and documentary sources on the problem under study, conducting expert research with heads of football academies (14 people) in connection with the application of brand management as a form of brand management and enforcement, researching and analyzing the experience of PFC "Levski" in the policy of imposing the brand among the fans.

As part of our work we used different research methods, such us: content analysis, survey method, with a strong expert focus and case studies.

During the research we analyzed the promotional tools used by football academies, their policy to create a club identity, the importance of quality in the creation and supplying the service of teaching and the professional training of young players.

A study of similar nature is a novelty for sports management practice in football. The conclusions and final recommendations can be used as a starting point in order to upgrade and diversify the forms of promotional policy of football academies.
\end{abstract}

OPEN ACCESS

Submitted: 8 June 2020 Revised: 14 September 202 Accepted: 25 March 2021

ORCID (1D

Nina Atanasova https://orcid.org/ 0000-0003-3425-6779 Emil Atanaso https://orcid.org/ 0000-0003-4742-2289

Cite this article as: Atanasova, N., Atanasov, E. (2021) Brand management - theory and practice in the football academies in Bulgaria Journal of Applied Sports Sciences, Vol.1, pp. 106-115. DOI: 10.37393/JASS.2021.01.9

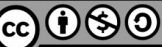

This work is licensed under a Attribution-Non

Commercial-ShareAlike 4.0 International (CC BY-NC-SA 4.0)

Key words: brand management, brand, corporate identity, marketing, football academies

\section{INTRODUCTION}

Modern sport develops in an extremely dynamic environment - a new legal framework, relatively changing economic indicators - income, inflation, GDP, highly developed technology sector, the dominant role of social media, the scientific advances in various training methods, the changes in the value system and consumer perceptions. All these processes lead to even more challenges which the management of some established commercial brands (including the sports ones) faces. The number of consumers is growing, and becoming more demanding and difficult to predict in terms of their interests and behavior, while competitors are coming to be more inventive and aggressive (Trendafilov, 2020).

Globally, there is probably no more significant manifestation of the rise of sports business than that observed in football. The indisputable dominance of the game is due to a number of factors: 1). geographical attraction - football is understandable to every nation on earth. 2). demographic - the accessibility and inclusion of people of different ages. 3). socio-cultural 
- sport is associated with all free and intended for entertainment and recreation activities. 4). recreation and entertainment - this game takes millions of people away from everyday life and stress. 5). economic environment and business industry - the high commercialism of football, expressed in the amounts generated for bonuses, transfers, salaries, advertising and TV rights, etc.

As a result, football attracts the attention of a number of researchers who study the management of football clubs and academies in different countries. A detailed analysis of the specific goals, objectives and football philosophy of youth football academies in Greece in accordance with the sector in which they operate (public, private or voluntary) was made by Chris Trikalis, Zisis Papanikolaou, and Sofia Trikali (2014). The authors summarized the results for the football academies for each of the listed sectors in the areas: management (strategic planning, philosophy, promotion, etc.); training process (goals, means, training plans, participation in competitions, control, etc.), and accompanying and supporting services (sports infrastructure, including the access to it, consultations with various specialists, physiotherapists, rehabilitators, nutritionists, psychologists, etc.).

Profiled marketing and corporate identity of the brand also find their place in various scientific and practical publications. Pursuing one of its main economic goals - financial stability, each club needs to apply the principles of corporate governance of the brand (Slavchev, 2009).

The brand is the promise a company makes to its customers (Kapferer, 2007). The value of the brand is measured as equity. According to Kotler (2002), this capital is "based on the degree to which there is high brand loyalty, name awareness, perceived quality, strong brand associations and other assets, such as trademarks". Globally, strong equity fosters a successful brand strategy and influences purchasing intentions, price premiums, and brand loyalty (Spry, Pappu and Cornwell, 2011).

Today, the literature views sports teams as brands in their own right (Mullin et al., 2007; Tsolov, 2008). The brand is considered the most important advantage of sports teams (Bauer et al., 2005). Brand and branding create a strategic lever for generating value for organizations (Keller and Lehmann, 2009), in sport in particular (Ross, 2006), both from a marketing and financial point of view (Mizik and Jacobson, 2008). According to I. Sandanski (2006), the brand is "the most valuable intellectual property on which the success of all current and future marketing initiatives of the club is built."

Sport is able to project influence far beyond the products and services it produces (De Angelis, 2016). It has the tools to build a strong loyalty relationship with its fans (consumers) which is stronger than any other industry. One of the leading questions in the management of sports organizations is how the value of the brand can be increased. The ways to achieve this can be different: increasing brand awareness, creating strong graphic symbols (icons), increasing the level of brand knowledge, increasing customer loyalty and satisfaction (fans).

Companies, represented by sports organizations, can create equity for their products by making them memorable, easily recognizable and superior in quality and reliability. To achieve this goal, the role of the media as a translator of ideas, products and services is essential. The theoretical and practical study of brand management as a strategic component in the management of sports organizations includes presentation and knowledge of the potential elements of the brand. In the scope of the existing theoretical approaches, we find 
the differentiation of the elements of the brand in four main directions (Meffert, \& Burmann, 1996):

1. Brand elements related to the product (quality characteristics, product design);

2. Elements related to symbols (brand, brand logo, brand history and brand communication);

3. Elements of the brand related to the organization (belonging to organizations, conglomerate or branches, employee behavior);

4. Brand elements related to consumers (cultural connection and perception).

An important practical direction in brand management is the imposition of company (organizational) identity, containing three components:

1. Corporate design - includes the logo of the sports organization and its use in various club documents, letterheads, folders, business cards and printed materials;

2. Corporate communications - club site, blog, advertising campaigns, public relations, media partnerships, distribution;

3. Corporate behavior - values of the sports organization, style in presenting the club idea and identity;

The identity of a football club is not just an association of the brand with players, coach and fans (Heere, James, 2007). In most cases, the club identity is influenced by a number of external factors such as: demographic affiliation, professional, public and other types of organizations, political parties - i.e. the identity of a club is mainly influenced by the character of its supporters (Budakov, 2016).

The purpose of the research was to study the experience and operational capabilities of some football academies in Bulgaria in creating a corporate identity and establishing a football brand. The research tasks related to the goal were:
1. Research of literary and documentary sources on the researched problem.

2. Expert research in football academies in connection with the application of brand management as a form of brand management and enforcement.

3. Research and analysis of the experience of PFC "Levski" in the policy of imposing the brand among the fans.

\section{METHODS}

For the realization of the complete research a toolkit was used, including the following research methods:

1. Content analysis - research and theoretical analysis of specialized literature, normative documents and programs, including:

- Scientific literature on issues of brand management (tools, goals and brand management), marketing, promotional and communication activities.

- Research of basic documents related to the management of the football academy and PFC "Levski”".

2. Methods of consultation with marketing orientation - survey among experts (managers and directors) of football academies in Bulgaria. The position of the respondents emphasizes the expert nature of the overall textual analysis.

To implement the tasks of the research, an expert card was designed, containing several main research areas: promotional tools used by the football academy, policy for creating a club identity, quality parameters in creating the service "training and professional training among young players".

3. Case study - used to describe a specific management situation related to the study of forms of communication and interaction of the football academy "Levski" to impose the brand among its fans.

For the overall implementation of the 
method, a large amount of specific information related to the specific case was collected. In the technological dimension, many structured and unstructured interviews were conducted.

4. Mathematical and statistical methods - Methods for quantitative evaluation of research data were used for analysis of the studies, including:

- relative percentage share of the answers received in the survey;

\section{RESULTS AND DISCUSSION}

"Vision for the future 2018-2022" is the main strategic document reflecting the efforts of the Bulgarian Football Union in the development of children and youth football in Bulgaria. One of the priorities in this strategic document is related to "building a football identity that brings pride and joy to the nation."

Creating identity plays an important role

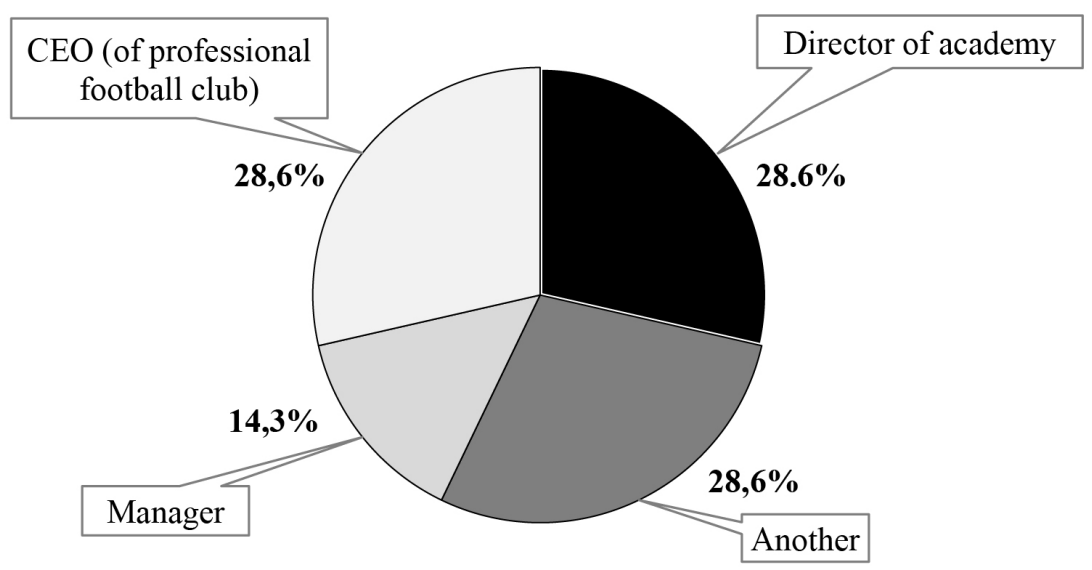

Figure 1. Occupation

The first part of the analysis was aimed at the establishment of promotional tools and the frequency with which they were used in football academies. The one-dimensional disribution of the results showed that among the most popular and preferred forms were the information on the club's website (used in $85 \%$ of the academies), corporate sponsor- in the behavior of organizations. Brand name, logo, motto, colors, symbols are some of the factors identifying organizations that impose the brand among consumers. The tools most often used by organizations, including sport ones, are advertising and other means of communication, sponsorship, social marketing tools, and more.

In the study on identity and organizational brand we analyzed the opinion of 14 experts, representing 14 football academies in Bulgaria, from the first and second professional leagues and academies aimed at the development of children and youth football.

On the basis of "gender", $100 \%$ of the experts were men between the ages of 28 and 47 . The position of the respondents is presented in Figure 1. The category "other" includes an administrative director ( 3 people) and 1 sports director of a club. 


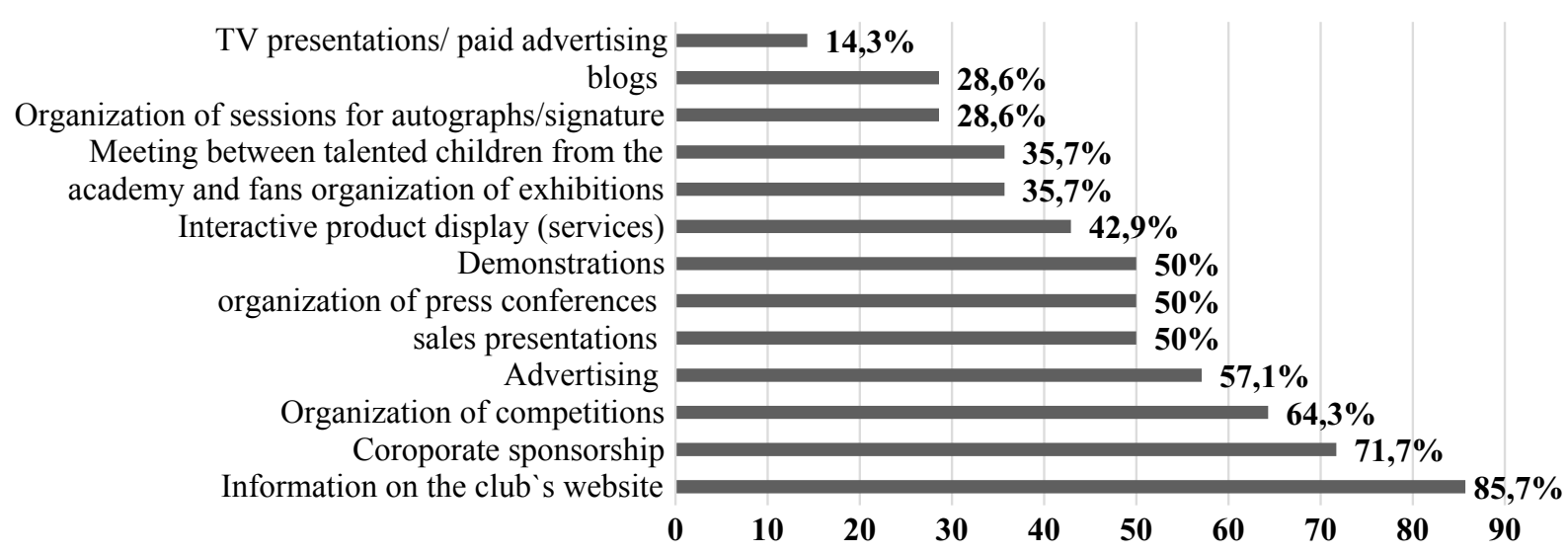

Figure 2. Promotion forms used by the football academies

We found some reservations in promoting the football academies. Our research showed that the modern and popular forms of communication - blogs were not used efficiently. Professionally designed textual comments and analyzes would add an extra nuance to everyday football events. Another not so popular form amongst football academies is the organization of autograph sessions.

Regarding the frequency of use of promotional activities (Figure 3), it should be noted that in $40 \%$ of the football clubs, corporate partnership contracts are concluded once a year. However, it is not to be overlooked that in $30 \%$ of the academies such contractual relations are established repeatedly during the season.

Raising public awareness of the directions in the activities of football academies, incl. organizing demonstration events, conducting national castings, performance and ranking in the championships, etc. is subject to subsequent analysis.

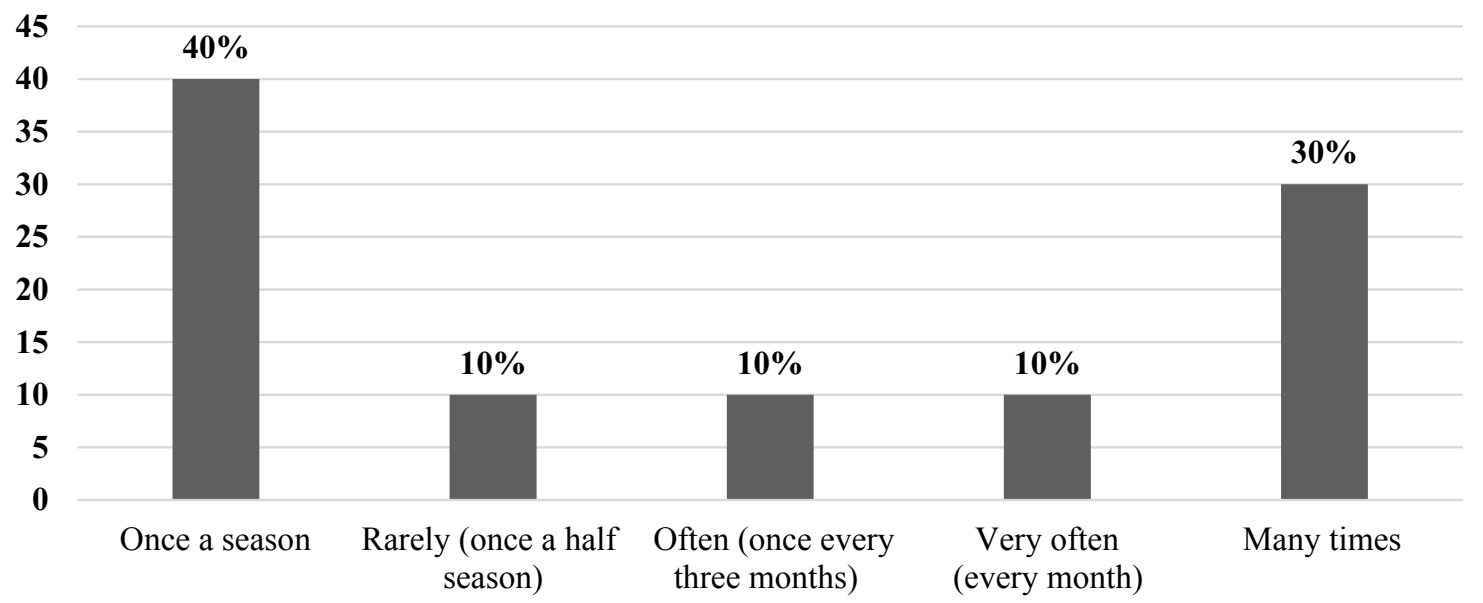

Figure 3. Frequency of distribution of corporate sponsorship

The statistics reflect the preferred sources for providing information amongst different audiences (Figure 4). The figure illustrates the percentage of sources used by the experts in the study. The Internet occupies the leading position. The academy's own site and official page in the social medias have a dominant role in the communication process with users. Targeted advertising is one of the most unpopular form of communication among fans and parents of young football players. 


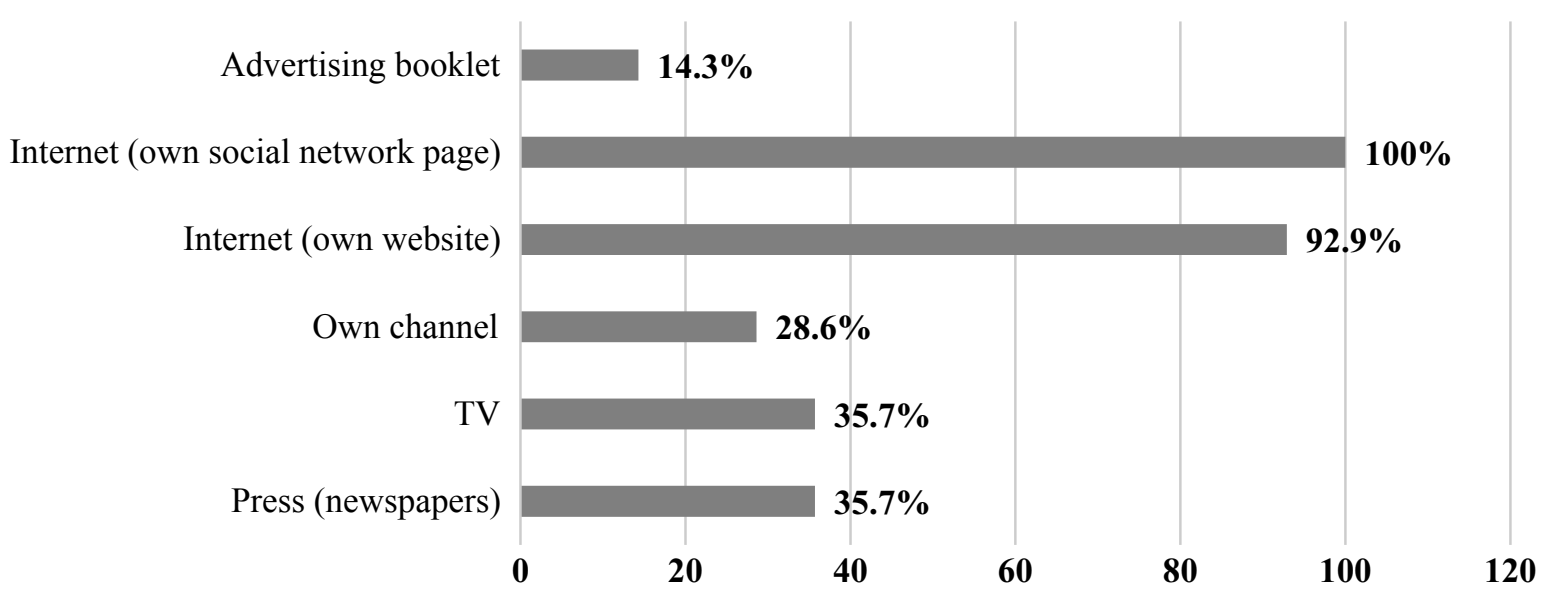

Figure 4. Preferred sources for providing information (possibility to indicate more than one answer)

The main strategy of the Bulgarian Football Union is raising the level of training and performance of children in youth football academies. The goal is to be achieved by 2022 . The growth can be realized through better coaching education, development of a methodology for training young athletes, integrative partnership with various institutions, incl. international ones, development and implementation of investment projects for construction of modern sports facilities, ensuring the safety of fans and everyone at football stadiums, etc.

All these activities are factors that greatly contribute to improving the service provided by football academies. In the next area of analysis, the importance of these factors will be commented on, according to the experts in the study. The expert card identified 11 components that determine the quality of the service.

The one-dimensional distribution of the results showed that the factors most important for the management of the football academies were the creation of a specialized methodology for training football players of different ages and the competence of the sports specialists who implemented the service $(92.6 \%)$. Both indicators have a strong educational character and involve various institutions such as the Bulgarian Football Coaching School at the Bulgarian Football Union, National Sports Academy which are responsible for the policy making, setting standards and developing coaches to help clubs.

The next group of important factors were related to the provision of the sports training process - the general condition of the sports infrastructure - training grounds, official pitches for home matches of the teams $(85.6 \%)$ and providing sufficient equipment and supplies (78.6\%).

The weak and insignificant factors were related to the provision of parking spaces near the facilities for home matches and the variety of fan items offered in the stores. 


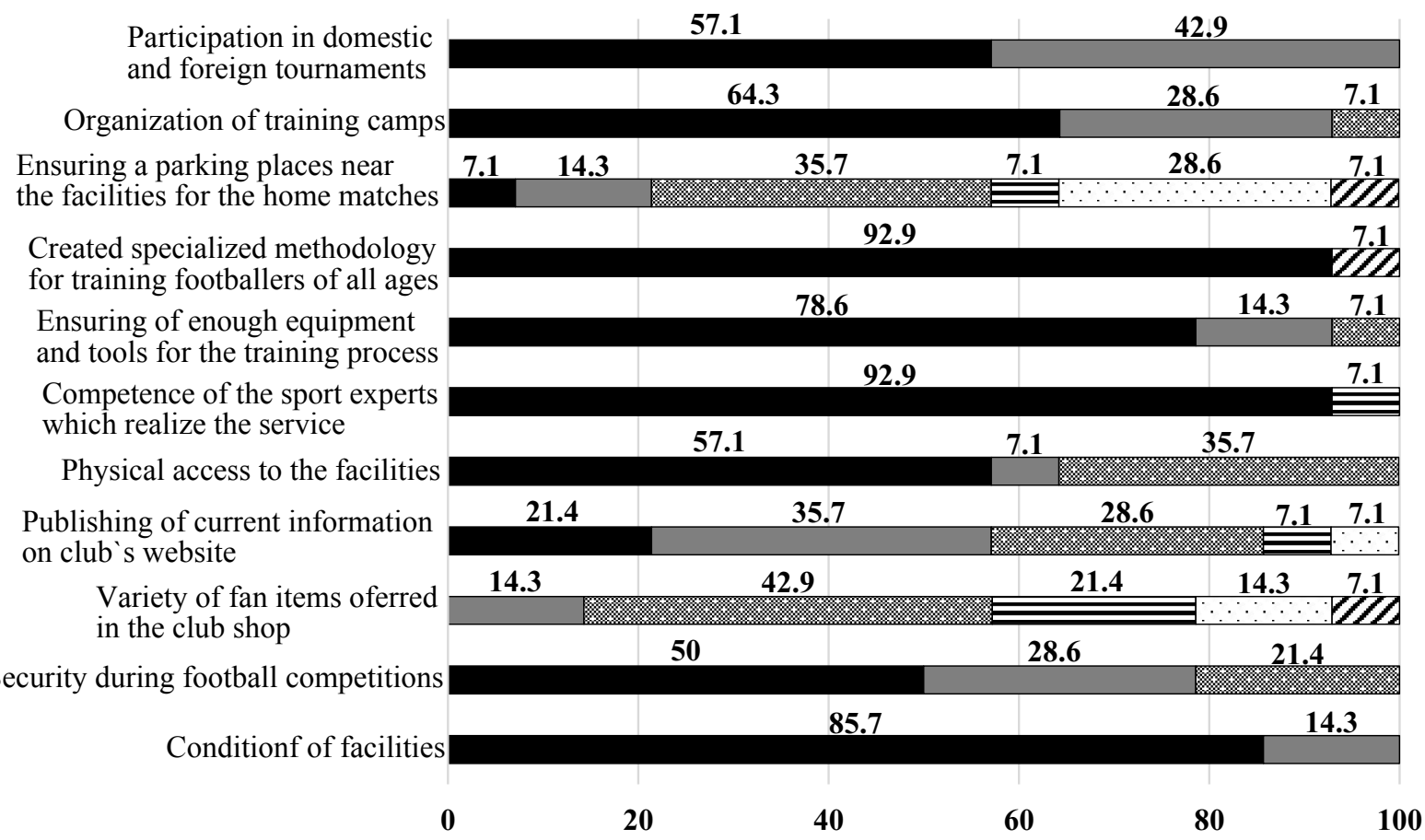

excellent meaning $\square$ very good meaning $\otimes$ good meaning $\boxminus$ middle meaning $\square$ weak meaning $\square$ without meaning

Figure 5. Importance of the factors determining the quality of the service "education and training of young football players" (in percentages)

Figure 6 illustrates the target group to which This is a large number of active athletes, which the offered service is directed. The leading academies carry out training sessions with children requires football academies to effectively and of different ages - between 300 and 400 chil- es - staff, material and technical, financial, scidren depending on the size of the organization. entific and technical, information.

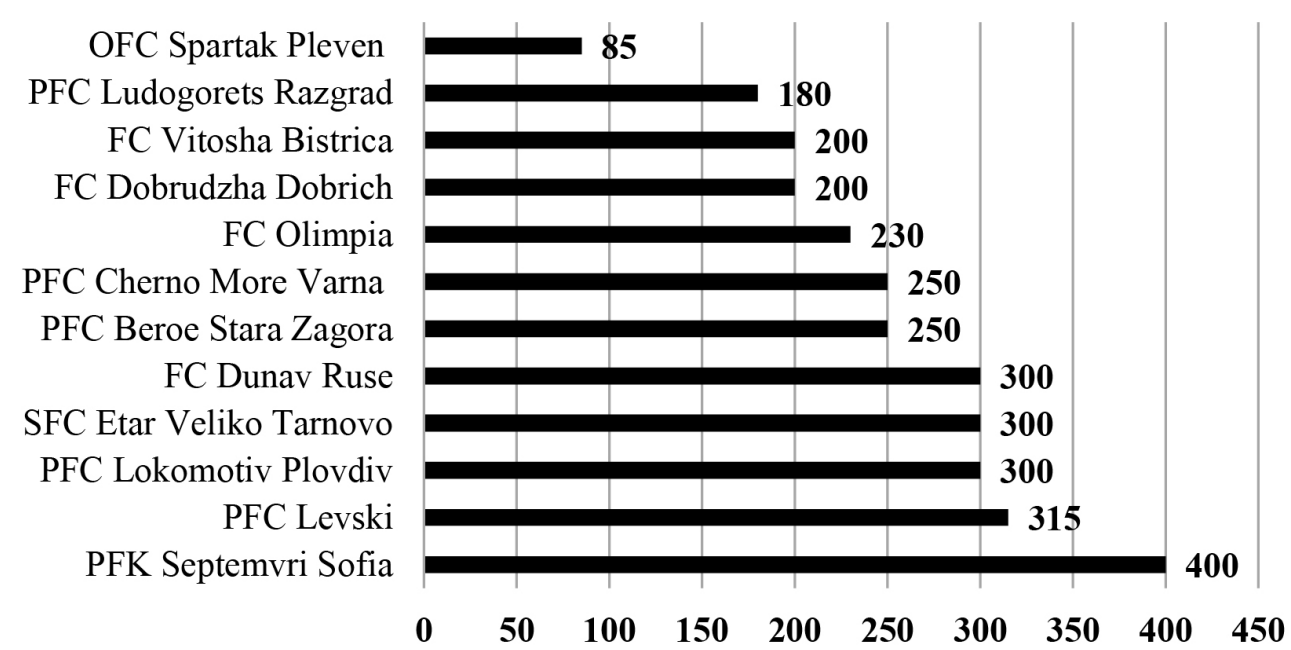

Figure 6. Number of children training in football academies

Corporate identity is the overall idea of the brand of the organization or product in the minds of people - consumers, partners, investors and others. The concept of the brand is associated with several concepts - brand identification (visual elements of the brand such as colors, logo, 
etc.); brand personalization (defining the business, mission, values, etc.); added value, positioning, recognizability, brand strategy, brand attributes (name, logo, slogan, mascot, advertising face, organization design, distinctive features on vehicles, etc.), user experience (feelings, emotions, thoughts, feelings, experience).

The object of analysis in the following direction is some of the communication constants that are used in sports practice to impose the brand. We researched and established the importance of 11 elements. The data is illustrated in Figure 7. Once again we see the dominant role of coaches $(92.9 \%)$ in managing the standards of football academies. The next priority element in the communication process for imposing the brand is the policy of the club in integrating football players from their own academies into the first team.

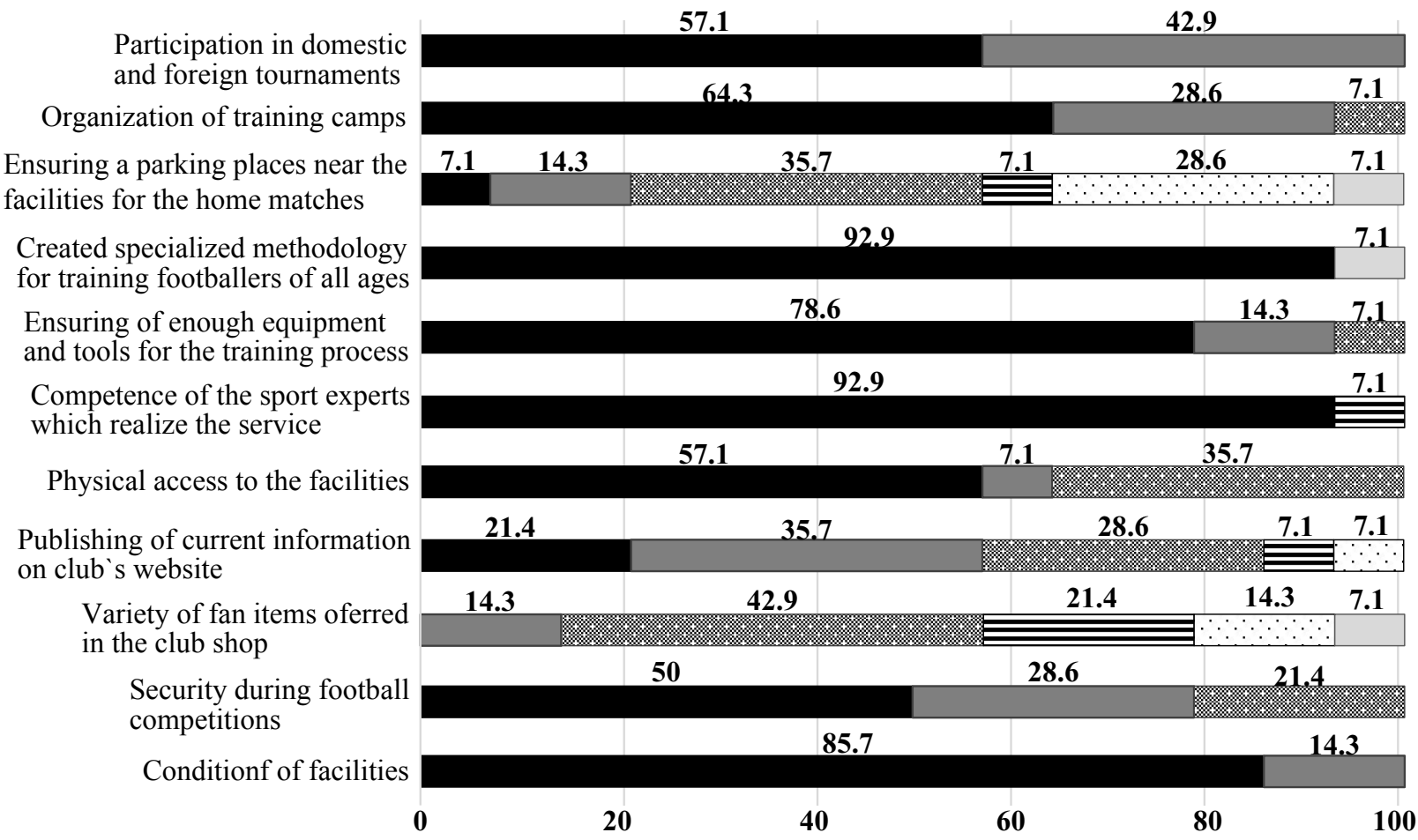

excellent meaning $\square$ very good meaning $\mathbb{2}$ good meaning $\boxminus$ middle meaning $\square$ weak meaning $\square$ without meaning

Figure 7. Importance of communication constants used to impose the brand among fans and consumers (in percentages)

This is essentially one of the most important quantitative measures of academy performance. The objective of most academies in Bulgaria is to successfully develop, implement and include more home-grown talents in their first team on professional level. The name of the football academy and its players have a significant importance (71.4\%). The communication elements defined with the least importance were the flag and the advertising slogan of the sports organization (7.7\%).

In the other scientific and practical direction, we will make an analysis of the communication policy applied by PFC Levski. The recent events accompanying the rescue of the club, with the active role of the fans, is a direct proof of the achieved level of corporate image and reputation. The implemented campaigns, compliant with the restrictive measures in our country due to the spread of COVID-19, are an example of activity on the part of the club's management in the use of marketing and communication strategies. Their scale directly affected the development of the football academy at the club. Some of the campaigns included:

1. Launch of virtual tickets for Efbet League matches; 
2. Opportunities for personalization by placing your face in the stands for matches behind closed doors after the resumption of the football championship in June;

3. The sale of virtual tickets for the 106th anniversary of the club;

4. Personalization and strong impact of advertising messages (slogans) in the individual campaigns - to report on the anniversary of the club - "one hundred and six with dignity and honor"; for virtual meetings - "for a full stadium... in hearts";

5. Organization of active purchase of membership cards.

6. Organization of a campaign for financial support in the HelpKarma platform;

7. Creation of a donation account;

8. Active sale of fan items from the club's stores, including the launch of new ones, specially created to activate the fan community due to COVID 19 - scarves, masks, etc. The items are divided into two categories: "Donors" and "All for Levski", differing in the presence or absence of personalization;

\section{CONCLUSION}

The obtained results allow to make an indepth analysis and to ask important questions about the policy of the football academies in Bulgaria in the process of imposing the brand amongst fans and potential consumer groups.

In general, the results of the research determine the main vision in the management of clubs and the use of sports marketing tools with a strong communication effect.

The results support the thesis that football academies use primarily known, popular and imposed in practice tools for promotional activity corporate sponsorship, organizing traditional tournaments, Internet dissemination of information.

The obtained and analyzed data are a good prerequisite and starting point for the academies, which in the future could expand and further de- velop the potential and efforts in imposing corporate identity. In the field of sports, especially in football, a large financial asset is the income from the fans - attendance at football matches, purchase of fan items. This indirectly affects the conclusion of contracts for television broadcasts, etc.

There are some unanswered questions in this research:

1. To what extent does the existing legal framework help or counteract the implementation of corporate partnerships?

2. What are the main advantages and disadvantages of the main promotional tools used by football academies?

3. Which communication constants are part of the arsenal of individual academies?

\section{REFERENCES}

Bauer, H. H., Sauer, N. E. and Schmitt, P. (2005). Customer-based brand equity in the team sport industry. European Journal of Marketing, 39(5/6): 496-513.

Budakov, P. (2016). Klubnata emblema - fundament za uvelichavane na razpoznavaemostta i populiarnostta na futbolnia klub. Are available at: http://eprints.nbu.bg/3064/1/ Club\%20emblems-Budakov-Final.pdf

Dowling, G. R. (1986). Managing Your Corporate Images. Industrial Marketing $\mathrm{Ma}$ nagement, 15, pp. 109-115.

Heere, B., James, D. J. (2007). Sports Teams and Their Communities: Examining the Influence of External Group Identities on Team Identity. Journal of Sport Management, 21, pp.319-337, Human Kinetics, Inc.

Kapferer, J. N. (2007). The New Strategic Brand Management: Creating and Sustaining Brand Equity Long Term. London, UK: Kogan Page.

Keller, K. L. and Lehmann, D. R. (2009). Assessing long-term brand potential. Journal of Brand Management, 17(1): 6-17.

Kotler, P. (2002). Marketing Management, 11th Edition. Upper Saddle River, NJ, USA: 
Prentice Hall.

Meffert, H. \& Burmann, C. (1996). Identitätsorientierte Markenführung (Arbeitspapier Nr. 100) [Identity-oriented Brand Management (working paper Nr. 100). Münster: WGMU.

Mizik, N. and Jacobson, R. (2008). The financial value impact of perceptual brand attributes. Journal of Marketing Research, 45(1): 15-32.

Mullin, B. J., Hardy, S. and Sutton, W. A. (2007). Sport Marketing, 3rd Edition. Champaign, Illinois: Human Kinetics.

Ross, S. D. (2006). A conceptual framework for understanding spectator-based brand equity. Journal of Sport Management, 20(1): 22-38.

Sandanski, I. (2006). Efektiven menidgmynt I sponsorstvo na uchilishten sporten klub, NSA Pres, Sofia.

Slavchev, I. (2009). Ekspertno prouchvane na nqkoi faktori na sponsorstvoto v lekata atletika. Sport I nauka, 4, Sofia, pp.53 - 61.

Spry, A., Pappu, R. and Cornwell, T. B. (2011). Celebrity endorsement, brand credibility and brand equity. European Journal of Marketing, 45(6): 882-909.

De Angelis, S. (2016) The Exploitation of Brand Equity in Football Clubs Across Countries Are available at: https://pdfs.semanticscholar.org/d6d2/4704983138f6cc81269d4c1 f6e 55ecde5e9e.pdf

Trendafilov, D. (n.d.). Tyrgovskata marka kato ikonomicheska stojnost i znak. Pozicioniraneto kato instrumnt za sydavane na otlichimost. Are available at: http://ebox.nbu.bg/semiotika10/view_lesson.php?id=171

Trendafilov, D. (n.d.). Edna strategia, mnogo celi: inovacia ili renovacia $\mathrm{v}$ upravlenieto na tyrgovskite marki. Are available at: http://eprints. nbu.bg/4182/1/OneStrategyManyObjectives BrandMan_DrDTrendafilov_2020.pdf

Trikalis, Ch., Papanikolaou, Z., Trikali, S. (2014). Developing Youth Football Academies in Greece: Managing Issues and Challenges, International Journal of Sport Management Recreation \& Tourism, Vol.14, pp.1-20. Are available at: https://www.researchgate.net/ publication/307847923_Developing_Youth_ Football_Academies_in_Greece_Managing Issues_and_Challenges

Tzolov, B. (2008). Osnovi na marketinga $v$ sporta. Monografia. Sofia.

Van Hoecke, J. (Ed.) (2011). The classification of youth academies in German professional football clubs. In H. Gammelsaeter, \& G. Bielons (Eds.), Proceedings of the 19th Conference of the European Association for Sport Management, 339-340. Madrid: GB Creation \& Advice Consulting.

2018-2022 Vizia za bydeshteto. Are available at: https://bfunion.bg/uploads/import/ files/Vizia_Za_Badeshteto_opt.pdf

\section{Corresponding author:}

Nina Atanasova

History and Management of Sport National Sports Academy "Vassil Levski" 21, Acad. Stefan Mladenov. Str. Studentski grad, Sofia 1700, Bulgaria E-mail:nnsa@abv.bg 